\title{
Codemixing and Effective Communication: A Study of University of Nigeria, Nsukka and Nnamdi Azikiwe University, Awka Undergraduates
}

\author{
Jane Chinelo Obasi \\ http://dx.doi./org/10.4314/ujah.v20i1.7
}

\begin{abstract}
Language is the basic reason communication is made possible. It is essentially a means of communication among the members of a society. Based on this, the research appraises the nature of language use in the University environment especially as it concerns students of the University of Nigeria, Nsukka and Nnamdi Azikiwe University, Awka, Nigeria. From the point of view of the theory of interactional sociolinguistics which uses discourse analysis to study how language users create meaning via social interactions, the study examines some peculiar codes that are used by the students of UNN and UNIZIK in their different locations: classrooms, hostels and relaxation centres; and how these codes create unimaginable meaning while communicating in English. These codes were tabulated and analysed based on their lexical and morphological implications. It is important to state that these codes are intelligible and acceptable among the users even though they make conscious effort not to use these codes in formal communications. However, when one is not familiar with the linguistic background of the users, the person may be at sea in the midst of these students during communication. Therefore, for one to understand these codes and the way students mix them in their English language expressions, one has to observe and study the linguistic structures of their language use.
\end{abstract}

Keywords: Code-mixing, effective communication, lexis, morphology 


\section{Introduction}

Communication deals with giving and receiving information with the objective of creating understanding. For communication to serve its purpose, it must be effective. Code, for Romaine (110) does not only refer to different languages, but also to "varieties of the same language as well as styles within a language". People can choose to use one code instead of another on a particular occasion. They may decide to mix or even switch the codes as the need arises and in different situations. Fishman (1965) asserts that "the relationship between language and social situation is inevitable". Code mixing as well as effective communication has attracted the attention of many scholars. However, effective speaking exists in a group when the "speaker's messages are so clear that the listeners respond as desired" (Klopf 76). In other words, the listeners grasp the clear message of the speaker and act accordingly. Code mixing, therefore, refers to the "mixing of various linguistic units (morphemes, words, modifiers, phrases, clauses and sentences) primarily from two participating grammatical systems within a sentence" (Bhatia and Ritchie 338). It is also defined as "a language phenomenon in which two codes or languages are used for the same message or communication" (Essien 272). Many problems have arisen as a result of ineffective communication in Standard English among students. Humans often listen in order to evaluate or judge what has been said, and so miss out on the important information being passed across. The speaker too is not innocent as he either does not flow naturally with the language use and so chooses his words carefully, or in some cases does not use the right words to express himself accordingly. This, however, is not always the case as communal settings like the university community filled with many students from different linguistic backgrounds develop different codes which they mix with their use of English language in their everyday social interactions. While most scholars focus of the bilingual aspect of code mixing, this study, instead, sets 
out to reveal the different students' codes and the problems associated with effective communication among the students of University of Nigeria, Nsukka (UNN) and Nnamdi Azikiwe University (UNIZIK). Considering the fact that the effects of the use of some codes peculiar to students of UNN and UNIZIK have not been investigated previously, it was observed in this study that these distinctive codes have been of concern to the current research and therefore attempts to investigate them. Language is not only used for official purposes of communication but also for the purpose of maintaining social relationship. It is in the light of the foregoing that students freely and comfortably use codes to communicate informally within themselves as social relationships do not properly flow with the formalities of language.

\section{Literature Review}

\subsection{Linguistic Studies on Code mixing}

When two languages come in contact, each tends to intrude on the other consciously or unconsciously. As a result of this, the repertoire of the speaker of more than one language tends to be overclouded by the languages, thus, code mixing occurs. Code mixing is a common linguistic occurrence which has attracted and will continue to attract more researchers to its field. Whralak (2013) in a study explores the characteristics of Thai-English code-switching in Hormones the Series in a bid to find out the extent in which code-switching reflects on the importance of the English language for media and Thai teenagers. He selects the Hormones the Series as a unique sampling as it has been recognized as a phenomenon in Thai Television. The theoretical framework used for the study is Kannaovakun and Gunther's (2003) classification of nativized features of code-mixing and the reconceptualization of intra-sentential code mixing. He observes five out of six types of common nativized features referred to in the framework viz; Truncation, Hybridization, Conversion, 
Semantic shift and Reduplication. He further reveals that Truncation appears the most because Thai people truncate words to shorter forms to make it easier to be understood and for the convenience of pronunciation ((Whralak 36-37).

Furthermore, Jayantilal (1998) in a study offers insights into the characteristics of the code mixing behaviour of four Malay women who habitually alternate between Malay and English in their email correspondence with each other. The study makes use of thirtyfive written email messages of these bilinguals whose language is relatively static, that is, they are neither in the process of acquisition nor attrition of any languages used in their communication (Jayantilal 63-71). It was further noted in the study that bilingual writers actively construct and display identity in their most informal correspondence with each other; their Malay identity on one hand and their identity as educated people on the other hand are also proficient in English. Ugot (2010) in a research paper examines the language choice and the twin phenomena of code switching and code mixing in a multi-lingual Biase Local Government Area in Cross River state, Nigeria. She observes the different languages spoken in Biase, from the local languages which serve as mother tongue (MT/L1) to other languages used in the local government which includes; English, Efik and the Nigerian Pidgin (NP). She posits that language choice in Biase is often motivated by "extra linguistic factors such as education, religion, economy and domestic use of language; hence, code switching is sanctioned especially by those who do not understand the L1 of the pivot speaker and that of the other hearer" (Ugot 28).

Communication is a two-way language exchange between a speaker and a listener. It is more than just speaking or writing. For communication to be effective, it requires the creation of a common understanding of ideas, desires and observations among people. Abdel-Rahman et al (2016) in their study aim to enhance the oral communication skills of Ajloun National University students (ANU). 
They observed that the students of ANU face many problems related to speaking skills such as; confusion and embarrassment. The limited amounts of vocabulary students have account for their lack of proper expression in English language. In the course of the study, the theory of Bailey (2005) and Goh's (2007) proposed methods for enhancing speaking skills by means of syllabus design. Teaching principle and speaking assessment was employed. The above study shows that the limited amounts of vocabulary students have account for their lack of proper expression in English language. This, however, is not the case in this current study because it is a culture for students who live in the university environment to use codes in communication even though this might make them look unintelligible in certain contexts.

Doi (39) investigates the communicative patterns of English learners, with Japanese as case study in conversational interaction, and explores what kinds of communication style they employ when they are communicating in English language. She uses 'Backchannel theory' as one of the effective strategies for boosting mutual understanding in conversational interaction and to analyze the data and gave instances of the way the English learners utter words in a conversation without turn-taking. She reveals that the elementary speakers in conversation often use cooperative strategies to compensate for grammatical insufficiency more than advanced speakers. They tend to rely highly on these cooperative pragmatic strategies to compensate for insufficiency of their grammatical competence more than advanced speakers. The above reviewed works are similar to the current research in that ineffective communication occurs when there are two languages involved. It is, however, dissimilar in the sense that this research identifies that one of the causes of ineffectiveness in students' communication skills in Standard English is as a result of code mixing. Again, the data, case studies and theoretical frameworks used are different. 
Code mixing affects effective communication among students. Obediah (2015), for instance, investigates the ideologies in slangy expressions with UNN students as the case study. In the cause of her investigation, she explores the effects and factors that give rise to the extensive use of slangy expressions among the students under study. She posits from her findings that students who "engage in slangy expressions belong to a single speech community based on a shared morality" and that they create for themselves the patterns of their linguistic behaviour so as to resemble those of the group(s) with which from time to time, they wish to be identified (Obediah 34). Offor (2012) aims at ascertaining the nature of informal classroom conversation among students of UNN. In this study, Obediah investigates the way the informality of classroom environment constrains the nature of conversation. He also examines the speech act of an informal conversation among equal and unequal students. Offor (5) observes that informal classroom conversations are done in the turn-taking system. He also states that "informal conversations among equals have great significance and mobilizing power as an ideal form of social interaction, but its actual occurrence in classes and powerridden society is extremely limited" (Offor 21).

Furthermore, Mmadike et al (2017) in their research examine the applicability and effectiveness in the use of code mixing and eclecticism in the teaching and learning of elementary Igbo for general purposes. With UNIZIK as the case study, they investigate the implication of the new L2 status of Igbo in the teaching and learning of Elementary Igbo courses in some departments of UNIZIK. The study focuses on checking the possibility of enabling the Elementary Igbo courses to consolidate the Basic Igbo Programme in enhancing the learners' Igbo communication skills in order to contribute to promoting the development of the Igbo language (Mmadike et al 88). Based on the research carried out in the course of this study, it was observed that most works written on code mixing and effective 
communication in English are mainly considered in the light of bilingualism.

Many scholars see code mixing as something that occurs only among people that have two or more languages in contact. Considering the fact that language is the way a group of people communicate, a university community being made up of different students from different linguistic backgrounds tend to form a neutral ground where everyone can flow using one language. This neutral ground happens to be their special way of communicating informally with one another. Based on this, students' codes are introduced. These students' codes, however, are sometimes if not always, mixed with the English language which is supposed to be the formal language in a Nigeria university environment. This is, therefore, considered code mixing among students. In the light of the foregoing, it becomes evident that no work has been done on code mixing and effective communication in English using the two universities under study as a case study. This constitutes the gap that this study intends to fill.

\section{Theoretical Framework}

This current study benefits from the theory of Interactional Sociolinguistics. Interactional sociolinguistics is a subdiscipline of linguistics that uses discourse analysis to study how language users create meaning via social interaction. It is an approach to discourse analysis that studies how people use language in face-to-face interaction. Specifically, it focuses on how people manage social identities and social activities as they interact. Interactional sociolinguistics derives from a variety of disciplines including ethnomethodology, conversation analysis, linguistics, pragmatics, linguistic anthropology, sociology, ethnography and dialectology. Interactional sociolinguistics draws on the work of John Gumperz (1982). Gumperz had a stronger theoretical influence and argued that communication is not a combination of talk and context; they are not 
discrete elements but rather that context is embedded in talk. Interactional sociolinguistics has a theoretical approach to language use and an accompanying methodological perspective. In essence, interactional sociolinguistics takes the view that talk is incomplete: that people are not able to say everything they mean explicitly enough when expressing themselves through talk. As a result, they cannot simply rely on the words that are used to appreciate what is meant. The words used alone are not sufficient to convey the full meaning and background knowledge is necessary to address the incompletion of spoken words. This is the case of students and code mixing which in turn affects effective communication in English. Put in another way, interactional sociolinguistics holds that because of the incompleteness of talk, all language users rely on other knowledge that is not communicated (but inferred): this is known as extracommunicative knowledge. Interactional sociolinguistics thus tries to describe how people in a conversation identify extracommunicative elements. It then analyses conversations to see if the contextualisation has worked in the production and reception of talk and whether that influences subsequent interaction. The concepts of notions of contextualization cues and conversational inferencing makes interactional sociolinguistics useful for exploring how talk and culture come together to create meaning. This theory, therefore, explains why students in an academic environment create unique codes which they mix with English language structures during communication in English even though they are found to use these codes in a more informal setting.

\section{Objectives of the Study}

Specifically, the study sets out to;

a) Investigate students' codes that do not have the authentic meaning of Standard English but are code mixed with English language expressions. 
b) Identify how these codes are used in different places like; classrooms, hostels, recreation areas and others places.

c) Examine how the use of these codes affects communication in English.

d) Analyse the codes based on their lexical and morphological structures.

\section{Methodology}

The data for this study was obtained from the University of Nigeria, Nsukka and Nnamdi Azikiwe University through audio-recording and note taking at various locations of the students: classrooms, relaxation areas, hostels and other areas on campus where students gather. Forty linguistic codes were gathered from the students of each of the sample universities (UNN and UNIZIK) to make a total of eighty codes which were examined and analysed. The purposive sampling technique was used to analyse the data. In this type of sampling, subjects are chosen to be part of the sample with specific purpose in mind. This type of sampling is considered best for this research as it gives the researcher the opportunity to select the subjects that are fit for the research. Therefore, not all the codes gathered for this study was analysed because of the large number. But the researcher through judgmental analysis only sampled few codes in the discussion session. Also, the utterances for most of these codes happened unconsciously. Most of the codes were therefore spontaneously picked or recorded by the researcher during relaxed conversations among the students. However, the students could not explain the origin of some of the codes they use except that they know the codes have been in existence long before they got to know and use them. The type of qualitative research method employed in this study is the descriptive method. This method enabled the researcher to describe the different codes used by students of the two universities under study. It also facilitated 
the use of tables to present the data in the course of the analyses as this gives the work clarity.

\section{Data Presentation for Table 1}

The data collected during the course of the study are presented and analyzed below. This category contains in a tabular form the codes gathered from the students of UNN.

Table 1: Codes Extracted from the Undergraduates of University of Nigeria, Nsukka Undergraduates (UNN)

\begin{tabular}{|l|l|l|l|}
\hline & Codes & Meanings & Illustrations \\
\hline 1 & Akpo & $\begin{array}{l}\text { Akpo is an Igbo word } \\
\text { that depicts strength. It } \\
\text { however, depicts } \\
\text { 'strictness' as students' } \\
\text { code }\end{array}$ & $\begin{array}{l}\text { That lecturer is a big } \\
\text { time akpo }\end{array}$ \\
\hline 2 & Lekpa & $\begin{array}{l}\text { Lekpa is a Yoruba word } \\
\text { that depicts 'slimness' }\end{array}$ & She is lekpa \\
\hline 3 & Ndi ogo & $\begin{array}{l}\text { Ndi ogo is an Igbo term } \\
\text { that means 'in-law', but } \\
\text { as a code, it is used to } \\
\text { refer to guys that usually } \\
\text { visit UNN girls' hostel }\end{array}$ & $\begin{array}{l}\text { Mary Slessor is the } \\
\text { hostel that has the } \\
\text { highest number of }\end{array}$ \\
\hline 5 & Orobo & $\begin{array}{l}\text { Ode means a stupid } \\
\text { person in Yoruba; it is } \\
\text { also used as a code to } \\
\text { refer to a 'stupid } \\
\text { person'. }\end{array}$ & $\begin{array}{l}\text { He acts like an } \\
\text { illiterate } \\
\text { Sometimes } \\
\text { down to the Yoruba } \\
\text { tribe to mean 'plump or } \\
\text { big'. Students adopted }\end{array}$ \\
\hline
\end{tabular}




\begin{tabular}{|c|c|c|c|}
\hline & & $\begin{array}{l}\text { this term to refer to } \\
\text { someone 'plump'. }\end{array}$ & \\
\hline 6 & Inhale & $\begin{array}{l}\text { Inhale is a code used } \\
\text { mostly by students who } \\
\text { smoke. It means to } \\
\text { 'smoke cocaine' }\end{array}$ & $\begin{array}{l}\text { John, inhale fast } \\
\text { let's move. }\end{array}$ \\
\hline 7 & Soft & $\begin{array}{l}\text { Soft is a code used for a } \\
\text { particular effect of drug } \\
\text { on someone who, } \\
\text { instead of being high, is } \\
\text { rather soft on drugs }\end{array}$ & $\begin{array}{l}\text { I have been soft } \\
\text { since morning to the } \\
\text { extent that I haven't } \\
\text { even had my } \\
\text { breakfast. }\end{array}$ \\
\hline 8 & $\begin{array}{l}\text { Moimoi } \\
\text { /beans }\end{array}$ & $\begin{array}{l}\text { Moimoi/ beans is a code } \\
\text { used to refer to } \\
\text { something that is not } \\
\text { easy to handle. }\end{array}$ & $\begin{array}{l}\text { Final year is not } \\
\text { moimoi }\end{array}$ \\
\hline 9 & Runs & $\begin{array}{l}\text { Runs is a code that } \\
\text { denotes illegal/ immoral } \\
\text { activities. It is used } \\
\text { mostly to relate to } \\
\text { examination } \\
\text { misconduct. }\end{array}$ & $\begin{array}{l}\text { He carries runs into } \\
\text { every exam hall }\end{array}$ \\
\hline 10 & Shait & $\begin{array}{l}\text { Shait is a code strictly } \\
\text { used by students of } \\
\text { UNN to denote 'the act } \\
\text { of passing excreta'. }\end{array}$ & $\begin{array}{l}\text { She shaits almost all } \\
\text { the time }\end{array}$ \\
\hline 11 & Mitshai & $\begin{array}{l}\text { Mitshai is an Hausa term } \\
\text { for their own kind of } \\
\text { 'tea' which students of } \\
\text { UNN call bread and egg } \\
\text { fried together by the }\end{array}$ & $\begin{array}{l}\text { Please buy me } \\
\text { mitshai on your way } \\
\text { back. }\end{array}$ \\
\hline
\end{tabular}




\begin{tabular}{|c|c|c|c|}
\hline & & $\begin{array}{l}\text { Hausas' in the school } \\
\text { environment. }\end{array}$ & \\
\hline 12 & Chaw & $\begin{array}{l}\text { Chaw is a code used by } \\
\text { students to denote 'eat' }\end{array}$ & $\begin{array}{l}\text { I'm coming to your } \\
\text { hostel to chaw } \\
\text { dinner. }\end{array}$ \\
\hline 13 & Voicemail & $\begin{array}{l}\text { Voicemail is a code that } \\
\text { means disappear/ } \\
\text { forgotten issue }\end{array}$ & $\begin{array}{l}\text { Pay up my money } \\
\text { before it enters } \\
\text { voicemail. }\end{array}$ \\
\hline 14 & Gats & $\begin{array}{l}\text { Gats means 'have/ has } \\
\text { to' }\end{array}$ & $\begin{array}{l}\text { You gats pay me up } \\
\text { real quick }\end{array}$ \\
\hline 15 & Runs girl & $\begin{array}{l}\text { Students refer to a runs } \\
\text { girl as a well-dressed } \\
\text { polished girl who } \\
\text { engages in a form of } \\
\text { 'high class prostitution'. }\end{array}$ & $\begin{array}{l}\text { That girl is a full } \\
\text { time runs babe }\end{array}$ \\
\hline 16 & Funky & $\begin{array}{lr}\text { Funky means } & \text { for } \\
\text { someone } & \text { to } \\
\text { important/classy. It is } \\
\text { usually used in a } \\
\text { sarcastic manner. }\end{array}$ & This babe feels funky \\
\hline 17 & Rake/ para & $\begin{array}{l}\text { To rake/para means to } \\
\text { shout on someone, } \\
\text { especially when you } \\
\text { seem to be in a higher } \\
\text { position. }\end{array}$ & $\begin{array}{l}\text { My roommate will } \\
\text { definitely para if she } \\
\text { finds out I used her } \\
\text { water. }\end{array}$ \\
\hline 18 & $\begin{array}{l}\text { Burst my } \\
\text { head }\end{array}$ & $\begin{array}{l}\text { To burst one's head } \\
\text { means to shockingly } \\
\text { amaze someone either } \\
\text { positively or negatively }\end{array}$ & $\begin{array}{l}\text { Guy, your lie just } \\
\text { burst my head finish. }\end{array}$ \\
\hline 19 & Whooze & $\begin{array}{l}\text { Whooze is a code from } \\
\text { 'whoosh' which means }\end{array}$ & 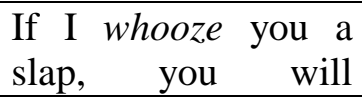 \\
\hline
\end{tabular}




\begin{tabular}{|c|c|c|c|}
\hline & & $\begin{array}{l}\text { to move quickly or } \\
\text { suddenly with a rushing } \\
\text { sound. As a code } \\
\text { however, whooze means } \\
\text { 'give resounding } \\
\text { slap/beat' }\end{array}$ & disappear. \\
\hline 20 & Off me & $\begin{array}{l}\text { Off me means to be } \\
\text { thrown off balance by } \\
\text { someone's speech or } \\
\text { action. }\end{array}$ & This your lie offs me \\
\hline 21 & Change (it) & $\begin{array}{l}\text { Change it means for } \\
\text { someone to act } \\
\text { differently, in a way } \\
\text { other than usual in order } \\
\text { to achieve a desired } \\
\text { effect. }\end{array}$ & $\begin{array}{l}\text { Don't try me; I'll } \\
\text { just change it for } \\
\text { you. }\end{array}$ \\
\hline 22 & Jonse & $\begin{array}{l}\text { Jonse means 'to joke'. } \\
\text { This is a common code } \\
\text { for students. }\end{array}$ & $\begin{array}{l}\text { He didn't mean any } \\
\text { insults, he was only } \\
\text { jonsing }\end{array}$ \\
\hline 23 & Ginger & $\begin{array}{l}\text { To ginger is to over } \\
\text { hype things }\end{array}$ & $\begin{array}{l}\text { She is a ginger } \\
\text { mama }\end{array}$ \\
\hline 24 & For Africa & $\begin{array}{l}\text { The expression for } \\
\text { Africa depicts } \\
\text { extremeness }\end{array}$ & $\begin{array}{l}\text { He can cook for } \\
\text { Africa }\end{array}$ \\
\hline 25 & Swear down & $\begin{array}{l}\text { Swear down means; } \\
\text { truthfully, } \\
\text { sincerely. }\end{array}$ & $\begin{array}{l}\text { You look very much } \\
\text { like your lecturer, I } \\
\text { swear down }\end{array}$ \\
\hline 26 & Fall hand & $\begin{array}{l}\text { To Fall hand means to } \\
\text { disappoint someone. }\end{array}$ & $\begin{array}{l}\text { She just likes falling } \\
\text { people's hands for } \\
\text { nothing }\end{array}$ \\
\hline
\end{tabular}




\begin{tabular}{|c|c|c|c|}
\hline 27 & Mad & $\begin{array}{l}\text { Mad means for } \\
\text { something to make extra } \\
\text { sense }\end{array}$ & $\begin{array}{l}\text { The turn up for the } \\
\text { show was mad }\end{array}$ \\
\hline 28 & Tidy & $\begin{array}{l}\text { Tidy means to assist in a } \\
\text { way }\end{array}$ & $\begin{array}{l}\text { He helps her tidy her } \\
\text { assignment most } \\
\text { times. }\end{array}$ \\
\hline 29 & On the low & $\begin{array}{l}\text { On the low means to lay } \\
\text { low in order to avoid } \\
\text { being noticed } \\
\text { unnecessarily }\end{array}$ & $\begin{array}{l}\text { Cultists in school are } \\
\text { currently operating } \\
\text { on the low }\end{array}$ \\
\hline 30 & Mattress & $\begin{array}{l}\text { Normally, mattress is a } \\
\text { soft fabric for sleeping. } \\
\text { But as a code, it means } \\
\text { 'matter'. It is students' } \\
\text { way of saying 'matter' }\end{array}$ & $\begin{array}{l}\text { There is no water in } \\
\text { the girls' hostel for } \\
\text { that mattress. }\end{array}$ \\
\hline 31 & Fashi & Fashi means to forget & $\begin{array}{l}\text { Fashi that girl, she } \\
\text { fakes a lot }\end{array}$ \\
\hline 32 & Form & Form means to pretend & $\begin{array}{l}\text { His clique of friends } \\
\text { are not really rich, } \\
\text { they are just forming }\end{array}$ \\
\hline 33 & $\begin{array}{l}\operatorname{Gee}(g+) \\
\text { guys }\end{array}$ & $\begin{array}{l}\text { Gee is the act of making } \\
\text { money through the } \\
\text { internet illegally that is } \\
\text { currently trending. }\end{array}$ & $\begin{array}{l}\text { Those guys are gee } \\
\text { guys, just be careful } \\
\text { around them. }\end{array}$ \\
\hline 34 & Wash & $\begin{array}{l}\text { Wash is to lie to } \\
\text { someone }\end{array}$ & $\begin{array}{l}\text { I never knew he was } \\
\text { washing me all along }\end{array}$ \\
\hline 35 & Whine & $\begin{array}{l}\text { Whine is somehow } \\
\text { related to 'wash,' but in } \\
\text { this case, it is seen as } \\
\text { lying in a continuous } \\
\text { and convincing manner. }\end{array}$ & $\begin{array}{l}\text { Nobody can whine } \\
\text { more than her }\end{array}$ \\
\hline 36 & Blow & Blow means success & sooner \\
\hline
\end{tabular}




\begin{tabular}{|l|l|l|l|}
\hline & & Plow, the better \\
\hline 37 & Pepper & Pcoper refers to money & He has made pepper \\
\hline 38 & $\begin{array}{l}\text { Scope is to analyze / } \\
\text { woo }\end{array}$ & $\begin{array}{l}\text { Have you even taken } \\
\text { your time to scope } \\
\text { her? She is really } \\
\text { beautiful. }\end{array}$ \\
\hline 40 & Ball/bounce & $\begin{array}{l}\text { Chyke literally means 'to } \\
\text { woo' }\end{array}$ & $\begin{array}{l}\text { Even broke guys } \\
\text { chyke ladies these } \\
\text { days. }\end{array}$ \\
\hline
\end{tabular}

\subsection{Discussion: Table 1}

Communication is a two-way process of exchanging information. For communication to be effective there has to be a feedback. Hence, both parties involved should be able to understand correctly the message being passed across. However, it was observed in this study that students do not use the codes gathered in the course of data collection according to the mechanics of language. This makes it difficult for them to communicate effectively and appropriately in Standard English because they have become used to these codes and therefore, apply them unconscious even in formal communication. The linguistic structures that were considered in the course of the analysis of this study are lexis and morphology. The discussion of the lexical items below is extracted from the Table 1 above. Also, the origins of some selected codes and how they are used in the different locations of the students on campus are shown.

\section{- Lexis}

i) Soft - 'soft' as an English lexical item means 'easily giving way under pressure'. As a code among the students of UNN however, it is a term that refers to a particular effect of drug on 
someone who, instead of being high, is soft on drugs. For instance,

- I have been soft since morning to the extent that I haven't even had my breakfast.

The sentence above implies that 'the speaker had been so weak as a result of drugs and so is unable to do anything including taking breakfast'. However, one who does not belong to this speech community would be wondering how a person can be 'soft' and then 'not have breakfast' because there is no relationship between the two. This is as a result of the fact that he does not understand the linguistic structures of the language that make up the students' culture. Soft is mostly used in the relaxation centres as this is where students cool off and take as much drinks as they wish.

ii) Beans - 'beans' as an English lexical item means 'a seed-like food'. However, its meaning as a student code is got from the ideology that this kind of food is difficult to cook. Hence, 'beans' refers to 'things that are difficult to handle'. For instance;

- Final year is not beans at all.

iii) Runs - the word 'runs' is a lexical item that depicts 'the plural form of run' which means 'moving with speed'. As a code however, it means 'illegal or immoral activity especially as regards to examination conduct'. For instance;

- He carries runs into the examination hall.

The sentence implies that the boy in question involves in exam malpractice. Irrespective of the fact that Runs is informal, it is mostly used in the classroom area as it involves academics.

iv) Mattress - this English lexical item means 'a bed', whereas it is used as a code in place of 'matter'. Hence, instead of using 'for that matter' in an utterance, students say 'for that mattress'. For instance;

- There is no water in the girls' hostel for that mattress. 
v) Wash - lexically implies 'cleaning', but means 'lying' as a code. For instance;

- I never knew he was washing me all along.

The above code which is mostly used in the hostel areas implies that 'the speaker has been lied to for some time'. However, a non-user of the students' codes will definitely misunderstand this statement.

vi) Pepper - is a lexical term that implies 'a hot seed', whereas it refers to 'money' as a code. For instance;

- He has made pepper.

A non-user of this language would be wondering how someone is able to make pepper instead of 'cultivating' them. The sentence above actually implies that 'the guy in question had made money'. However, the code pepper is mostly used in the hostels and relaxation centres, as these are where students spend money.

vii) Akpo - is an Igbo lexical item that depicts strength. As a code, it depicts 'strictness'.

- For instance; that lecturer is a big time akpo.

This sentence implies that the lecturer is a very strict person. Akpo is used by students mostly in the classroom area.

viii) Lekpa - a Yoruba word which means 'slim'.

For instance; she is lekpa

The sentence above implies 'the slimness of the girl'. This code from Yoruba (a tribe in Nigeria) origin is used mostly in the hostel areas, as this is where students discuss and gossip mostly.

ix) Ndi ogo - is an Igbo word which means 'in law'. As a code, it is used to refer to the males that usually visit UNN girls' hostels.

For instance; Mary Slessor is the hostel that has the highest number of ndi ogo.

The above sentence implies that the male visitors in Mary Slessor hostel are usually more than any other hostel in UNN campus. This code originates from Igbo language and is used mostly in the hostel areas. 
x) Mitshai - mitshai is an Hausa term for their own kind of 'tea'. As a code however, it means 'bread and egg fried together by the Hausas' in the school environment'.

For instance; please buy me mitshai on your way back. This code is mostly used in the school and hostel areas because they are bought and eaten in these areas.

\section{Morphology}

This section explores the data that explains the way students of UNN coin words to form codes and the way these codes differ in meaning with Standard English.

xi) Off me - this literally means 'turn someone out'. As a code however, it means 'to weaken'. For instance;

- The way he answers questions offs me

The context of the expression as a code has helped shape the meaning which only the users would understand. The sentence hence, implies that 'the speaker is weakened by the way the boy answers questions'.

xii) Burst my head - this means to 'break one's head' in the literal sense, but as students' code, it means ability to amaze someone either positively or negatively. For instance;

- Guy, the way you lie bursts my brain.

The above expression would seem unintelligible to someone who is not conversant with the codes used by students in this environment but to the students here, it is very intelligible among them.

xiii) On the low - this word formation literally means 'not rising', but in a context where it is used as a code among the students, it means 'lesser degree'. For instance,

- Cultists in school are currently operating on the low.

The above sentence implies that 'the school cultists are operating on a lesser degree to avoid being noticed and sanctioned. 


\section{2: Data Presentation for Table 2}

Table 2: Codes Extracted from the Undergraduates of Nnamdi Azikiwe University, Awka (UNIZIK)

\begin{tabular}{|l|l|l|l|}
\hline & Codes & Meanings & Illustrations \\
\hline 1 & Scores & $\begin{array}{l}\text { Scores refer to news } \\
\text { or stories about } \\
\text { someone }\end{array}$ & $\begin{array}{l}\text { I hear your } \\
\text { scores these } \\
\text { days }\end{array}$ \\
\hline 3 & Lash/straf/potash & $\begin{array}{l}\text { Normally, lash means } \\
\text { 'to whip' with a stick; } \\
\text { however, as a code, it } \\
\text { means to 'have sex' } \\
\text { Lash/straf/potash can } \\
\text { be unted to } \\
\text { interchangeably. }\end{array}$ \\
$\begin{array}{l}\text { lash her in front } \\
\text { of everyone. }\end{array}$ \\
\hline 4 & Ball & $\begin{array}{l}\text { Ball means to go/ to } \\
\text { leave }\end{array}$ & $\begin{array}{l}\text { I want to ball } \\
\text { soon }\end{array}$ \\
\hline 5 & Street & $\begin{array}{l}\text { Street means to } \\
\text { deceive someone }\end{array}$ & $\begin{array}{l}\text { Let's street them } \\
\text { to join us to club } \\
\text { tonight }\end{array}$ \\
\hline 6 & Off & $\begin{array}{l}\text { To off is surprise or } \\
\text { even I just off } \\
\text { someone by your } \\
\text { action.' }\end{array}$ & $\begin{array}{l}\text { i. I } \\
\text { completely }\end{array}$ \\
\hline 7 & 'H' & $\begin{array}{l}\text { His code that refers } \\
\text { to 'being hungry' }\end{array}$ & $\begin{array}{l}\text { Omo I dey H } \\
\text { badly } \\
\text { (pidgin/slang) }\end{array}$ \\
\hline 8 & Gum body & $\begin{array}{l}\text { Gum body means to be } \\
\text { so attached to } \\
\text { someone, even when } \\
\text { the person doesn't } \\
\text { want you around }\end{array}$ & $\begin{array}{l}\text { Her gum body is } \\
\text { too much }\end{array}$ \\
\hline 9 & Reason & $\begin{array}{l}\text { To reason is to } \\
\text { I want to reason }\end{array}$ \\
\hline
\end{tabular}




\begin{tabular}{|c|c|c|c|}
\hline & & $\begin{array}{l}\text { explain something to } \\
\text { someone }\end{array}$ & $\begin{array}{l}\text { this business } \\
\text { with you }\end{array}$ \\
\hline 10 & Align & $\begin{array}{l}\text { Align means to work } \\
\text { together in a } \\
\text { suspicious manner }\end{array}$ & $\begin{array}{l}\text { Come lets align } \\
\text { now }\end{array}$ \\
\hline 11 & Bar & $\begin{array}{l}\text { Bar means money at } \\
\text { hand }\end{array}$ & $\begin{array}{l}\text { Are you with } \\
\text { some bar? }\end{array}$ \\
\hline 12 & On the low & $\begin{array}{l}\text { To be on a low is to } \\
\text { lay low in order to } \\
\text { avoid being noticed } \\
\text { unnecessarily. }\end{array}$ & $\begin{array}{l}\text { He has been on } \\
\text { the low for some } \\
\text { months now }\end{array}$ \\
\hline 13 & Make- waka & $\begin{array}{l}\text { To make-waka means } \\
\text { to 'join cult' }\end{array}$ & $\begin{array}{l}\text { Shockingly, } \\
\text { girls make-waka } \\
\text { these days more } \\
\text { than guys }\end{array}$ \\
\hline 14 & Mobs & $\begin{array}{l}\text { Cars are referred to as } \\
\text { mobs }\end{array}$ & $\begin{array}{l}\text { Those guys } \\
\text { came on mobs }\end{array}$ \\
\hline 15 & Yakpaa & $\begin{array}{l}\text { Yakpaa is a Yoruba } \\
\text { word 'Yapa' which } \\
\text { means 'plenty'. The } \\
\text { misspelling of the } \\
\text { word is for better } \\
\text { pronunciation and } \\
\text { convenience for non- } \\
\text { Yoruba students. }\end{array}$ & $\begin{array}{l}\text { Cars yakpaa for } \\
\text { this place }\end{array}$ \\
\hline 16 & Tidy & $\begin{array}{l}\text { Tidy means to arrange } \\
\text { in a 'coded' way }\end{array}$ & $\begin{array}{l}\text { Guy, help me } \\
\text { tidy some babes } \\
\text { for my birthday } \\
\text { party }\end{array}$ \\
\hline 17 & Sly/corner & $\begin{array}{l}\text { Students } \\
\text { sly/corner in a slangy } \\
\text { way to mean to }\end{array}$ & $\begin{array}{l}\text { i. Guy you don } \\
\text { sly me (pidgin) } \\
\text { ii. I almost got }\end{array}$ \\
\hline
\end{tabular}




\begin{tabular}{|l|l|l|l|}
\hline & & deceive. & $\begin{array}{l}\text { lornered by } \\
\text { those cult guys }\end{array}$ \\
\hline 18 & Injection & $\begin{array}{l}\text { Injection means to } \\
\text { 'inhale cocaine' }\end{array}$ & $\begin{array}{l}\text { This morning } \\
\text { injection "make } \\
\text { sense" die } \\
\text { (Slang) }\end{array}$ \\
\hline 19 & Burst my head & $\begin{array}{l}\text { Burst my head means } \\
\text { to really 'wow' } \\
\text { someone }\end{array}$ & $\begin{array}{l}\text { Her dance steps } \\
\text { bursts my head }\end{array}$ \\
\hline 21 & Change 'it' & $\begin{array}{l}\text { Change it means for } \\
\text { someone to switch } \\
\text { moods especially to } \\
\text { turn violent. }\end{array}$ & $\begin{array}{l}\text { He changed it } \\
\text { for her after she } \\
\text { annoyed him }\end{array}$ \\
\hline 22 & Yati yati & $\begin{array}{l}\text { Yati yati is said to be } \\
\text { an Igbo expression } \\
\text { which means to talk } \\
\text { without making sense }\end{array}$ & $\begin{array}{l}\text { We all know that } \\
\text { you talk yati yati } \\
\text { almost always }\end{array}$ \\
\hline 23 & Jonse & $\begin{array}{l}\text { This is a common } \\
\text { code for students } \\
\text { which means to 'joke' }\end{array}$ & $\begin{array}{l}\text { You jonse alot, } \\
\text { just be serious } \\
\text { for once }\end{array}$ \\
\hline 24 & Ginger & $\begin{array}{l}\text { Means to over-hype } \\
\text { one's ability to do } \\
\text { things }\end{array}$ & $\begin{array}{l}\text { She cannot do } \\
\text { anything; She's } \\
\text { just gingering }\end{array}$ \\
\hline 25 & Make brains & $\begin{array}{l}\text { It's a code students } \\
\text { use to suggest that } \\
\text { 'something really } \\
\text { makes sense' }\end{array}$ & $\begin{array}{l}\text { Her dressing } \\
\text { always make } \\
\text { brains }\end{array}$ \\
\hline 26 & To run & $\begin{array}{l}\text { Means truthfully, } \\
\text { honestly, sincerely }\end{array}$ & $\begin{array}{l}\text { You are a very } \\
\text { nice person I } \\
\text { swear down }\end{array}$ \\
\hline Means to do/ arrange & Guy, \\
\hline
\end{tabular}




\begin{tabular}{|c|c|c|c|}
\hline & & something & $\begin{array}{l}\text { quickly run the } \\
\text { package }\end{array}$ \\
\hline 28 & Run me on & To give something & $\begin{array}{l}\text { Joy, please run } \\
\text { me on fifty } \\
\text { 'bucks' } \\
\text { (50naira) }\end{array}$ \\
\hline 29 & Norms & $\begin{array}{l}\text { Norms is used to refer } \\
\text { to when something is } \\
\text { normal. }\end{array}$ & $\begin{array}{l}\text { That one is } \\
\text { norms nah }\end{array}$ \\
\hline 30 & Smalls & $\begin{array}{l}\text { Smalls is used to refer } \\
\text { to small things that } \\
\text { one can easily take } \\
\text { care of. }\end{array}$ & $\begin{array}{l}\text { Taking care of it } \\
\text { won't be a } \\
\text { problem, it's just } \\
\text { smalls. }\end{array}$ \\
\hline 31 & Kum level & $\begin{array}{l}\text { Means on a very low } \\
\text { level. }\end{array}$ & $\begin{array}{l}\text { He runs his } \\
\text { business on a } \\
\text { kum level. }\end{array}$ \\
\hline 32 & High & $\begin{array}{l}\text { Means to be highly } \\
\text { intoxicated }\end{array}$ & $\begin{array}{l}\text { Guy, I don high } \\
\text { (pidgin) }\end{array}$ \\
\hline 33 & Wash & To lie to someone & $\begin{array}{l}\text { Just take } \\
\text { anything he tells } \\
\text { you as a wash. }\end{array}$ \\
\hline 34 & Parole & $\begin{array}{l}\text { Used in place of } \\
\text { something in order to } \\
\text { maintain the secrecy } \\
\text { of the gist }\end{array}$ & $\begin{array}{l}\text { This kind of } \\
\text { parole is norms } \\
\text { nah (Slang) }\end{array}$ \\
\hline 35 & Chyke & Means to woo a lady & $\begin{array}{l}\text { I chyked that girl } \\
\text { and she fell for } \\
\text { me }\end{array}$ \\
\hline 36 & Beans & $\begin{array}{l}\text { Means nothing/ no big } \\
\text { deal }\end{array}$ & $\begin{array}{l}\text { The 'ish' is } \\
\text { beans 'nah', I } \\
\text { will help you }\end{array}$ \\
\hline 37 & Package & Usually used & I gats package \\
\hline
\end{tabular}




\begin{tabular}{|l|l|l|l|}
\hline & & $\begin{array}{l}\text { people forming what } \\
\text { they are not, doing } \\
\text { things only in a way to } \\
\text { belong. }\end{array}$ & for this show \\
\hline 38 & Ish & $\begin{array}{l}\text { Means matter/issue at } \\
\text { hand }\end{array}$ & $\begin{array}{l}\text { Relate the ish to } \\
\text { him; he might be } \\
\text { able to give you } \\
\text { some money }\end{array}$ \\
\hline 39 & Maintain & $\begin{array}{l}\text { This means to act as if } \\
\text { everything is alright }\end{array}$ & $\begin{array}{l}\text { Guy, I know you } \\
\text { are broke, but } \\
\text { just maintain }\end{array}$ \\
\hline 40 & Blow & To succeed & $\begin{array}{l}\text { I just want to } \\
\text { blow sharply }\end{array}$ \\
\hline
\end{tabular}

\subsection{Discussion: Table 2}

In Table 2, the linguistic structures of some of the codes used by students of Nnamdi Azikiwe University as regards to lexis and morphology and how they differ largely from the Standard English language are revealed. Also the origins of some selected codes and how they are used in different environments in school are shown below.

\section{Lexis}

i) Ball - ball is a lexical item that means 'round body/ mass' whereas, as a code it means 'to leave/go'. For instance;

- I want to ball soon.

The above expression may not make sense to someone who is not conversant with the linguistic environment of the students hence, creating a gap in communication.

ii) Scores - this lexically means 'number of points', whereas it means 'news/stories' as a code in UNIZIK. For instance;

- I hear your scores at all times. 
The above sentence implies that the speaker hears news about the person being talked about. This code is mostly used in the hostels and relaxation centres as this is where students have fun and talk more.

iii) Street - 'street' is an English lexical item which means 'a paved part of a road', whereas as a code, it means 'to deceive' someone. For instance;

- Let's go and street them

The above sentence implies the 'speaker's intention to go and deceive some intended individuals'.

iv) Soft - means 'easy to press' whereas as a code, it refers to 'one's possession of money'. Notice the difference as regards the meaning of this code between UNN and UNIZIK. It depicts 'the effect of drugs' as a UNN code, and 'wealth' as a UNIZIK code. For instance;

- The guy is too soft.

To someone who is not acculturated in the use of this code, he/she may be thinking that the sentence above means that "the guy in question is soft hearted'. This, however, is not the intended message of the speaker. The above sentence implies that 'the guy is very wealthy'. This code is mostly used in the relaxation centres as this is where students spend and show off their wealth.

v) Bar - as a code means 'money at hand'. Money is spent mostly at relaxation centres, therefore, students are often seen to use this code there. For instance;

- Eat anything you want, I have bar to spend.

vi) Mobs - lexically means 'crowd', whereas as a code in this university environment, it means 'cars/ride'. For instance;

- Those guys came on mobs.

The sentence above implies that 'the guys came in their cars'. This code is usually used in the relaxation centres .

vii) Blow - lexically means 'explode', whereas, as a code it means 'success'. For instance;

- I just want to blow. 
This implies the 'speaker's quest for immediate success'. This code is mostly used in the hostels and relaxation centres as these are the likely places where students gather to discuss.

viii) Yati yati - is an Igbo lexical item which means to 'speak without making sense'. For instance;

- We all know that you talk yati yati always, even in class.

The above sentence implies 'constant pointless talks'. This code originated from Igbo language and it can be used by students anywhere on campus as one's speech can be considered pointless anywhere.

ix) Ode - means 'a stupid person' in Yoruba. For instance;

- You are a big ode.

The above sentence implies 'the height of the stupidity of the person being talked about'. This code originated from Yoruba language and it is used mostly in the hostel area where there is a quarrel or a fight.

\section{Morphology}

The analysis in this session explores the coinages from the students of UNIZIK used in their English expressions which differ markedly in meaning from the Standard English.

$\mathrm{x})$ Run me on - as a code means 'to give'. For instance,

- Run me on fifty bucks please.

The above sentence implies 'the speaker's wish to be given fifty bucks'. The context of the expression as a code has helped shape the meaning which only the users would understand. This code is used mostly in the hostel, relaxation areas and other places where money is spent.

xi) Kum level - this word may not make sense to a non-user of this code. However, it means 'on a lower degree or low level'. For instance;

- He runs his business on a kum level. 
xii) To run - literally means 'to move at a quick pace', but in this context as a code, it means 'to do something'. For instance;

- Guy, let me go and run the food. I'm hungry.

The speaker in the above sentence wishes to go cook the food because he's hungry. This code is mostly used in the hostels or school lodges.

xiii) Make brains - is a code students use to suggest that 'something really makes sense'. Literally, it implies the 'production of brains' which makes no sense. For instance;

- Her makeup always make brains.

This code can be used anywhere in the school environment.

It is pertinent to note that in this study, a non-user of the students' codes would be lost in a conversation between the students of these university communities as their usage of codes differ from the Standard English meanings. Hence, only the members of these speech communities would understand how they are used. This however, is what makes them unique as a culture, and validates the use of the theory of Interactional Sociolinguistics which reveals that communication involves contextualization cues which are culturally specific and usually unconscious.

This section has therefore, succeeded in analyzing the linguistic structures in terms of lexis and morphology of some selected codes from the two schools under study. It is important to note that some of the codes used in this study do not have factual basis. In fact, the origins of some were very difficult to source because they have been in use for a long time before they were written down. It was observed however that whether the codes are new or old, they are adopted by students and used accordingly in their different environments on the two campuses. This implies their coordinateness as a community. It was also observed that some of the identified codes feature in the language use of the undergraduates of the two universities under study. For instance codes like, T.D.B (till day break); gats (have to / has to); rake/ para (to shout at someone); 
jonse (joke); chyke (to woo a lady); ball (to go/leave), among many others. The use of the above identified common codes among the students of the two universities under study shows that these students have some kind of relatedness in their use of language on campus.

\section{Conclusions and Implications}

Code mixing in language use is inevitable among students. They always find a way to coin words to suit their environment. There are so many codes used by students on various campuses. This study has succeeded in revealing the various codes used by students, their origins, meanings and illustrations. It was observed in the course of the analysis that the use of codes has affected effective communication in English language among these students. This is as a result of the fact that these students still unconsciously use these non standard codes in formal occasions and it impinges on their ability to express themselves in English effectively especially during formal occasions like examination and classroom situations. More still, speakers of English who do not belong to this speech community do not understand how these codes are used, and for communication to be effective both parties involved should be able to understand each other adequately and give feedbacks. This cannot be achieved between a non-user and a user of the language; hence, making communication ineffective. However, even though, these codes are intelligible among the students, efforts should be made by language teachers to see that these codes only feature in informal communications and do not interfere in formal situations as such interferences should be penalized. This will in turn promote the conscious use of Standard English expressions among University students. 


\section{Jane Chinelo Obasi}

Department of English and

Literary Studies,

University of Nigeria, Nsukka

jane.obasi@unn.edu.ng

\section{References}

Abdel- Rahman, Al-Eideh. et al. "Improving English Language Speaking Skills of Ajloun National University Students". International Journal of English and Education 5

(2016):181-195. Print.

Bailey, Kathleen M. Practical English Language Teaching: Speaking. New York: McGraw-Hill. 2005. Print.

Bhatia, Tej, and William Ritchie. "Social and Psychological Factors in Language Mixing". Handbook of Bilingualism. Oxford: Blackwell Publishing. 2012. 336-352. Print.

Doi, Kaori. " An Analysis of Conversation Styles of English Learners-backchannels as Effective Strategies in Communication". The Bulletin of Institute of Technologies 3 (2012): 38-41.

Print.

Essien, Okon. "The Language and Code-Mixing: A case study of the Phenomenon in Ibibio". Global Journal of Humanities (2010): 27-35. Print.

Fishman, Joshua. "Who Speaks What Language to Whom and When?" La Linguistique 2.2 (1965): 67-88.Print.

Goh, Christine C.M. Teaching Speaking in the Language Classroom.

Singapore: SEAMEO Regional Language Centre. 2001. Print.

Gumperz, John. "Discourse Strategies". Studies in Interactional

Sociolinguistics 1. Cambridge: Cambridge University Press, 1982. Print. 
Jayantilal, Rekha. "Code-switching and Transfer in Email Correspondence Exchanged between Four Malaysian Women”. Journal Pendidikan Tigaenf 2. 2 (1998): 63-78. Print.

Klopf, Donald W. Interacting in Groups: Theory and Practice. Denver: Morton Publishing Company. 1981. Print.

Mmadike, Benjamin I., Nwankwere, Angela U.N. \& Eme, Cecilia A. "Eclecticism in the Igbo Language Classroom". International Journal of Language, Literature Gender Studies (LALIGENS) 6 (2017): 86-103. Print.

Obediah, Augustina. Ideologies in Slangy Expressions used by Students of the University of Nigeria, Nsukka. Unpublished project of the University of Nigeria, Nsukka. 2015.

Offor, Okechukwu. A Discourse Analysis of Informal Classroom Conversations of Students of the University of Nigeria. Unpublished project of the University of Nigeria, Nsukka. 2012.

Romaine, Suzanne. "Language in Society: An Introduction to Sociolinguistics. Bilingualism 25, Reviewed by Felice Anne Coles. Oxford: Oxford University Press. 1994.110. Print.

Whralak, Papijit. Thai-English Code-mixing in Hormones the Series. Masters Thesis of the School of Language and Communication, National Institute of Development Administration, Chiang Mai University. 2013. Print.

Ugot, Mercy. "Language Choice, Code-switching and Code-mixing in Biase". Global Journal of Humanities 8 (2010): 27-35. Print. 